\title{
Bioremediation Potential Assessment of Plant Growth-Promoting Autochthonous Bacteria: a Lignite Mine Case Study
}

\author{
Saud Hamidović ${ }^{1}$, Smilja Teodorović²*, Blažo Lalević ${ }^{3}$, Jelena Jovičić-Petrović ${ }^{3}$, \\ Jelena Jović ${ }^{4}$, Dragan Kiković ${ }^{5}$, Vera Raičević ${ }^{3}$ \\ ${ }^{1}$ Faculty of Agriculture and Food Sciences, \\ Zmaja od Bosne 8, 71000 Sarajevo, Bosnia and Herzegovina \\ ${ }^{2}$ Forensics Department, Academy of Criminalistic and Police Studies, \\ Cara Dušana 196, 11080 Zemun-Belgrade, Serbia \\ ${ }^{3}$ Department of Microbial Ecology, Faculty of Agriculture, University of Belgrade, \\ Nemanjina 6,11080 Zemun-Belgrade, Serbia \\ ${ }^{4}$ Department of Plant Pests, Institute for Plant Protection and Environment, \\ Banatska 33, 11080 Zemun-Belgrade, Serbia \\ ${ }^{5}$ Faculty of Natural Science and Mathematics, University of Pristina, \\ 38220 Kosovska Mitrovica, Serbia
}

Received: 6 February 2015

Accepted: 19 September 2015

\begin{abstract}
Coal and lignite play a major energy supply role in many European countries, including Bosnia and Herzegovina. Yet mining activities are a heavy source of ecosystem contamination, posing significant environmental threats. The primary goal of this study was to isolate and identify autochthonous lignite mine spoil bacteria and evaluate their potential in bioremediation of these polluted soils. Two Bacillus species, Bacillus simplex and a Bacillus cereus group member, were identified using conventional, molecular, and bioinformatics approaches. This represents, to our knowledge, the first microbial characterization of mine overburden in Bosnia and Herzegovina. A co-inoculum of autochthonous bacterial populations was used to treat unvegetated as well as oat- and lettuce-vegetated lignite overburden samples. Our results illustrate the potential of recovered native species to enrich soil fertility and productivity through plant growth promotion.
\end{abstract}

Keywords: Bacillus spp., soil, bioremediation, lignite spoil

\section{Introduction}

Around $40 \%$ of power generated globally is based on hard coal and lignite ${ }^{1}$, yet mining activities produce a high volume of mine overburden and tailings [1], causing

*e-mail: smiljateodorovic@gmail.com

${ }^{1}$ http://www.euracoal.org/ soil errosion, heavy metal contamination, and acid mine drainage that leads to contamination of adjecent waters and agricultural land, thus posing severe environmental and health risks in vast areas surrounding mines [2]. While traditional chemical approaches to restorting these contaminated soils are not sufficiently efficient [3, 4], phytoremediation is a cost-effective, non-invasive strategy with promising results in the field [reviewed in 5]. However, given that the success of this approach 
is considerably constrained by a slow remediation rate, varying field factors, and root depth [5], substantial research efforts have focused on utilizing microorganisms [6-8] and plant-microbe interactions [9-11] to restore mine tailings and overburden.

In the present study, we investigated overburden soil (OS) from the Kakanj lignite mine, a significant coal production plant providing main fuels for power generation in Bosnia and Herzegovina (BiH) at $44^{\circ} 7.912 \mathrm{~N} 18^{\circ} 5.84$ E [12]. Yet given that two thirds of Kakanj's production comes from surface mining, OS generation and disposal are of great concern. The main idea behind our approach was to identify and characterize mine OS autochtonous bacterial populations and assess their potential in restoring soil productivity and fertility, as measured by two plant species: lettuce (Lactuca sativa L.) and oat (Avena sativa L.).

\section{Experimental Procedures}

\section{Chemical and Microbiological Characterization of OS and Soil Samples}

OS samples $(0-20 \mathrm{~cm})$ collected from Kakanj in in July 2011 and control soil (S) samples $(0-15 \mathrm{~cm})$ collected from land under corn (Pancevo, Serbia) were used to create independent composite OS and S samples in the laboratory, which were chemically analyzed. Basic chemical properties of OS samples were determined according to [13]. Micronutrients and heavy metals were determined by atomic absorption spectroscopy (AAS), while organic pollutants were determined by gas chromatography-mass spectrometry (GC/MSD) and gas chromatography-flame ionization detector (GC/FID). OS samples were diluted in serial dilutions and plated (in triplicates) to ascertain the total number of microorganisms on $0.1 \mathrm{x}$ tryptic soy agar (TSA), ammonifying bacteria on meat peptone agar (MPA), Azotobacter sp. and oligonitrophilic bacteria on Fyodorov agar, fungi on rose bengal streptomycin agar, and actinomycetes on starch-ammonia agar. Soil was dried at $105^{\circ} \mathrm{C}$ for $2 \mathrm{~h}$ and the number of microorganisms was estimated as CFU/g dry soil.

Dehydrogenase (DHA) activity was determined by the method of Casida et al. [14] and reported as $\mu \mathrm{g} \mathrm{TPF} / \mathrm{g} / \mathrm{h}$.

\section{Identification of Bacteria from OS Samples}

$13 \mathrm{k}$ and 19k MPA colony and cell morphology were determined by a light microscope (Leica DMSL, Germany), while biochemical identification was conducted by API CH using the APIWEB system v. 1.1.0 (bioMerieux, Inc., France). Partial 16S rRNA gene was amplified from both isolates using total extracted DNA (DNeasy Blood \& Tissue Kit, QIAGEN), universal 16S rDNA primers (27F 5'GAGAGTTTGATCCTGGCTCAG3' and 1523R 5'AGGAGGTGATCCAGCCG3'), and KAPATaq polymerase (KAPA Biosystems). Amplified products were purified (QIAquick PCR Purification Kit, QIAGEN) and sequenced (Macrogen Inc., Seul, South Korea). Sequences were deposited in NCBI GenBank database under accession numbers KF494373 for isolate 13k and KF494374 for isolate 19k.

DNA sequence similarity searches were performed using the Ribosomal Database Project (RDP; http://rdp. cme.msu.edu). Reference Bacillus 16S rDNA sequences were aligned and used to construct the phylogenetic tree using the maximum parsimony method, with statistical support obtained by generating 500 bootstrap replicates in MEGA 6 [15].

\section{Greenhouse Cultivation}

Lactuca sativa L. (10 seeds/cup) and Avena sati$v a$ L. (5 seeds/cup), previously sterilized in $30 \% \mathrm{H}_{2} \mathrm{O}_{2}$ for $20 \mathrm{~s}$, were seeded at $1 \mathrm{~cm}$ depth in 5 substrates: $100 \%$ OS, $75 \%$ OS, $50 \%$ OS, $25 \%$ OS, and control (100\% $\mathrm{S})$ in 10 replicates, five of which were co-inoculated with $13 \mathrm{k} / 19 \mathrm{k}$ isolates $(10 \%, \mathrm{w} / \mathrm{w})$. The inoculum was prepared as follows: nutrient broth was inoculated with $13 \mathrm{k}$ and $19 \mathrm{k}$ pure cultures, incubated in an orbital shaker $\left(30^{\circ} \mathrm{C}\right.$, $150 \mathrm{rpm}$ ) for $24 \mathrm{~h}$, and $10^{8}$ cells $/ 0.01 \mathrm{M}$ phosphate buffer were used to inoculate the substrates. Plants were allowed to germinate for 25 days, removed from the substrate, and used to assess the total number of microorganisms ( $\mathrm{CFU} / \mathrm{g}$ dry soil), germination rate (\%), and shoot and root dry biomass ( $\mathrm{g} /$ substrate), following natural drying, as well as oven drying at $60^{\circ} \mathrm{C}$ for $120 \mathrm{~min}$.

\section{Statistical Analyses}

Obtained results were subjected to analysis of variance (ANOVA) using Statistica software (StatSoft, US). Mean values of data were compared by Fisher's LSD test at significance level $\mathrm{p}=0.05$.

\section{Results and Discussion}

\section{Chemical and Microbial Characteristics of Mine Overburden}

Kakanj OS samples were found to be acidic $\left(\mathrm{pH}_{\mathrm{KCl}} 5.23\right)$, with elevated organic $\mathrm{C}$ content $(15.28 \%$ vs. $1.86 \%)$ and an enhanced $\mathrm{C} / \mathrm{N}$ ratio (31.4:1 vs. 8.5:1; Table 1). The dominant form of nitrogen is ammonia (23.8 $\mathrm{mg} / \mathrm{kg}$ ), resulting from microbial mineralization of organic matter, while nitrification activity at $\mathrm{pH} 5.23$ is low (Table 1). Analysis of microelements and heavy metals [16] revealed that OS material is deficient in $\mathrm{P}$ $(30.0 \mathrm{mg} / \mathrm{kg})$ and $\mathrm{Mg}(268.0 \mathrm{mg} / \mathrm{kg})$, and rich in $\mathrm{Fe}$ (3.69 mg/kg), Ca (3372.0 mg/kg), Cd (0.70 mg/kg), and $\mathrm{Ni}(167.80 \mathrm{mg} / \mathrm{kg})$. Bioavailability of toxic metals such as $\mathrm{Ni}, \mathrm{Pb}$, and $\mathrm{Cd}$ has been shown to increase at $\mathrm{pH} 5$ [17].

The vast majority $(\sim 90 \%)$ of total microorganisms $\left(12.19 \times 10^{4} \mathrm{CFU} / \mathrm{g}\right)$ were contributed by oligonitrophilic $\left(7.45 \times 10^{4} \mathrm{CFU} / \mathrm{g}\right)$ and ammonifying $\left(3.39 \times 10^{4} \mathrm{CFU} / \mathrm{g}\right)$ 
Table 1. Chemical properties of overburden soil (OS) and soil (S) samples.

\begin{tabular}{|c|c|c|c|c|c|c|c|c|c|}
\hline & $\begin{array}{c}\mathrm{pH} \\
\left(\mathrm{H}_{2} \mathrm{O}\right)\end{array}$ & $\begin{array}{c}\mathrm{pH} \\
(\mathrm{KCl})\end{array}$ & $\begin{array}{c}\mathrm{CaCO}_{3} \\
(\%)\end{array}$ & $\begin{array}{c}\mathrm{C}_{\text {org }} \\
(\%)\end{array}$ & $\begin{array}{c}\mathrm{N}_{\text {tot }} \\
(\%)\end{array}$ & $\begin{array}{c}\mathrm{P}_{2} \mathrm{O}_{5} \mathrm{mg} / \\
\mathrm{kg}\end{array}$ & $\begin{array}{c}\mathrm{K}_{2} \mathrm{O} \\
\mathrm{mg} / \mathrm{kg}\end{array}$ & $\begin{array}{c}\mathrm{NH}_{4} \\
\mathrm{mg} / \mathrm{kg}\end{array}$ & $\begin{array}{c}\mathrm{NO}_{3} \\
\mathrm{mg} / \mathrm{kg}\end{array}$ \\
\hline $\mathrm{OS}$ & 5.96 & 5.23 & 0.0 & 15.28 & 0.486 & 30.0 & 129.0 & 23.8 & 8.4 \\
\hline $\mathrm{S}$ & 8.21 & 7.72 & 3.9 & 1.86 & 0.218 & 200.0 & 128.0 & 3.5 & 45.5 \\
\hline OS* & 3.69 & 268.0 & 0.70 & 24.86 & 84.97 & 167.80 & 23.90 & 0.291 & $\begin{array}{c}\text { Total } \\
\text { PAHs }\end{array}$ \\
\hline
\end{tabular}

*Total microelement, heavy metal, and organic pollutant content in overburden soil are given in $\mathrm{mg} / \mathrm{kg}$

Table 2. Dehydrogenase activity (DHA) in various overburden (OS) samples (x10-5 $\mu \mathrm{g} \mathrm{TPF} / \mathrm{g} / \mathrm{h})$.

\begin{tabular}{|c|c|c|c|c|c|}
\hline & Unvegetated OS & Non-inoculated oat & Inoculated oat & Non-inoculated lettuce & Inoculated lettuce \\
\hline Mean & 0.24 & 0.63 & 0.97 & 0.20 & 0.76 \\
\hline SE & 0.02 & 0.13 & 0.09 & 0.03 & 0.06 \\
\hline
\end{tabular}

bacteria, while fungi and actinomycetes were present in small amounts $\left(1.15 \times 10^{4}\right.$ and $0.2 \times 10^{4} \mathrm{CFU} / \mathrm{g}$, respectively; Fig. 1). Our results coincide with findings that oligonitrophilic bacteria dominate in nitrogendeficient soils [18]. Azotobacter sp. were not detected (Fig. 1), illustrating sensitivity to soil acidity, given that they are typically found in soil $\mathrm{pH} 7.1-9.0[19,20]$. As a bioindicator of soil fertility $[21,22]$, OS DHA activity was determined to be $0.24 \times 10^{-5} \mu \mathrm{g} \mathrm{TPF} / \mathrm{g} / \mathrm{h}$ (Table 2).

\section{Identification of Autochthonous Mine Overburden Bacteria}

Unlike the majority of previous research on plant growth promoting (PGP) microorganisms, which focused on Gram negative bacteria [23, 24], we decided to explore ammonifying bacteria. Macroscopic investigation of MPA plates resulted in two types of morphologically distinguishable colonies: $13 \mathrm{k}$ and $19 \mathrm{k}$. Isolate $13 \mathrm{k}$ colonies were large (2-6 $\mathrm{mm}$ in diameter), white-yellowish in color, circular to irregular shape, and moist (data not shown). Isolate $19 \mathrm{k}$ was depicted by 1-3 $\mathrm{mm}$ in diameter, whiteyellowish, irregularly shaped colonies spread across agar (data not shown). Microscopic examination of both $13 \mathrm{k}$ and $19 \mathrm{k}$ revealed Gram-positive, spore-forming, rodshaped bacteria without capsule (data not shown). The APIWEB technique, following incubation on API 50CH, suggested that $13 \mathrm{k}$ and $19 \mathrm{k}$ isolates exhibit the highest similarity to Bacillus thuringiensis and Paenibacillus alvei, respectively. Given constraints of the technique, molecular characterization was also performed.

Comparisons of $13 \mathrm{k}$ and $19 \mathrm{k} 16 \mathrm{~S}$ rDNA sequence against a RDP database placed both isolates in the genus Bacillus, which agrees with the data of others examining mine waste [25]. Isolate $13 \mathrm{k}$ exhibited $100 \%$ identity with $B$. simplex isolates, but also with a $B$. muralis and a

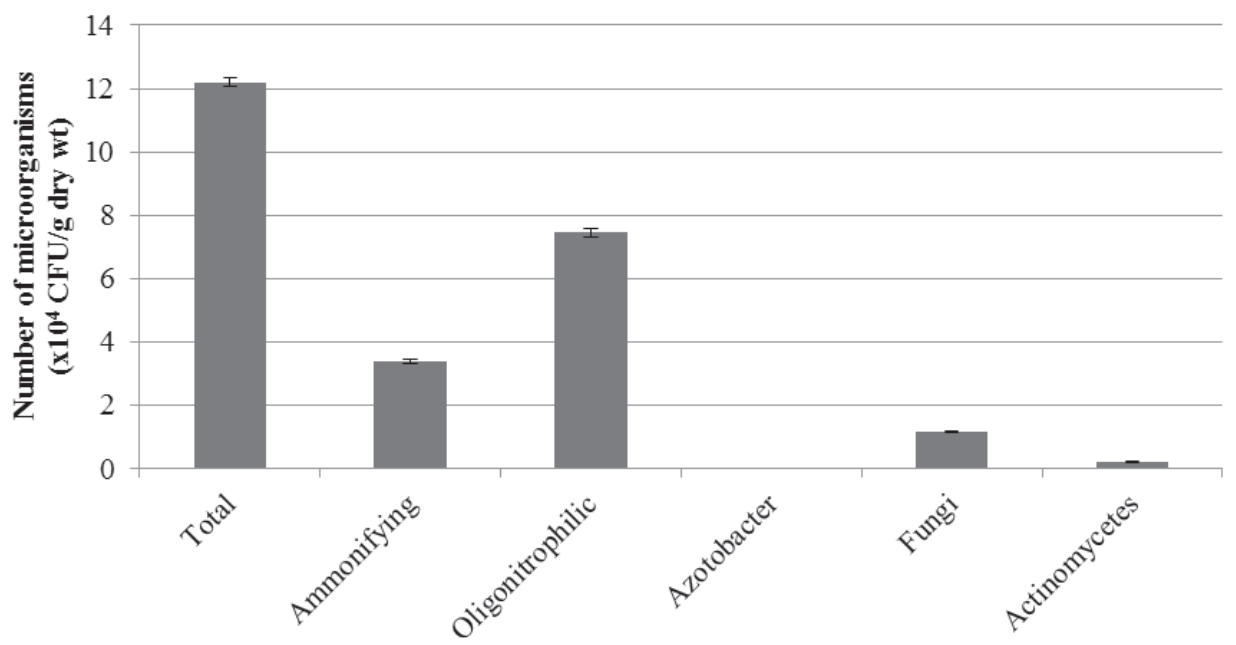

Fig. 1. Mean number of total microorganisms, ammonifying bacteria, oligonitrophilic bacteria, Azotobacter, fungi, and Actinomycetes in unvegetated mine overburden soil (OS) samples. 
Brevibacterium $s p$. isolate (data not shown). A proposed set of distinguishing biochemical characteristics between $B$. simplex and $B$. muralis [26] suggested that $13 \mathrm{k}$ behaves as $B$. simplex. Phylogenetic analysis of soil Bacillus $s p$. representatives revealed that isolate $13 \mathrm{k}$ grouped with $B$. simplex (Fig. 2). Isolate 19K showed $100 \%$ identity with $B$. thuringiensis and B. cereus isolates (data not shown), while it grouped within a $B$. cereus group $[27,28]$ in the phylogenetic analysis (Fig. 2).

\section{Effect of $13 \mathrm{k} / 19 \mathrm{k}$ Co-Inoculation} on Overburden Bacterial Community

In order to stimulate microbial abundance and diversity, we seeded pure and soil-assisted OS samples with oat (Avena sativa L.) and lettuce (Lactuca sativa L.). Lettuce was chosen due to its known sensitivity to environmental factors, such as increased heavy metal and salt concentrations [29], while fast-growing and easily managed, oat has been selected by many authors as a useful test for detection of toxic substances [30]. The total number of microorganisms in pure OS samples increased from $12.2 \times 10^{4} \mathrm{CFU} / \mathrm{g}$ (Fig. 1) in an unvegetated sample to $2.45 \times 10^{6}$ and $2.02 \times 10^{6} \mathrm{CFU} / \mathrm{g}$ in oat- and lettuceseeded OS, respectively (Fig. 3). The total number of microorganisms continued to increase with increase in soil content, where 50:50 OS-to-S ratio mimicked the microbial abundance of fertile soil (Fig. 3). Our data show that root exudates significantly affect microbial abundance in soil, as reported elsewhere [31].

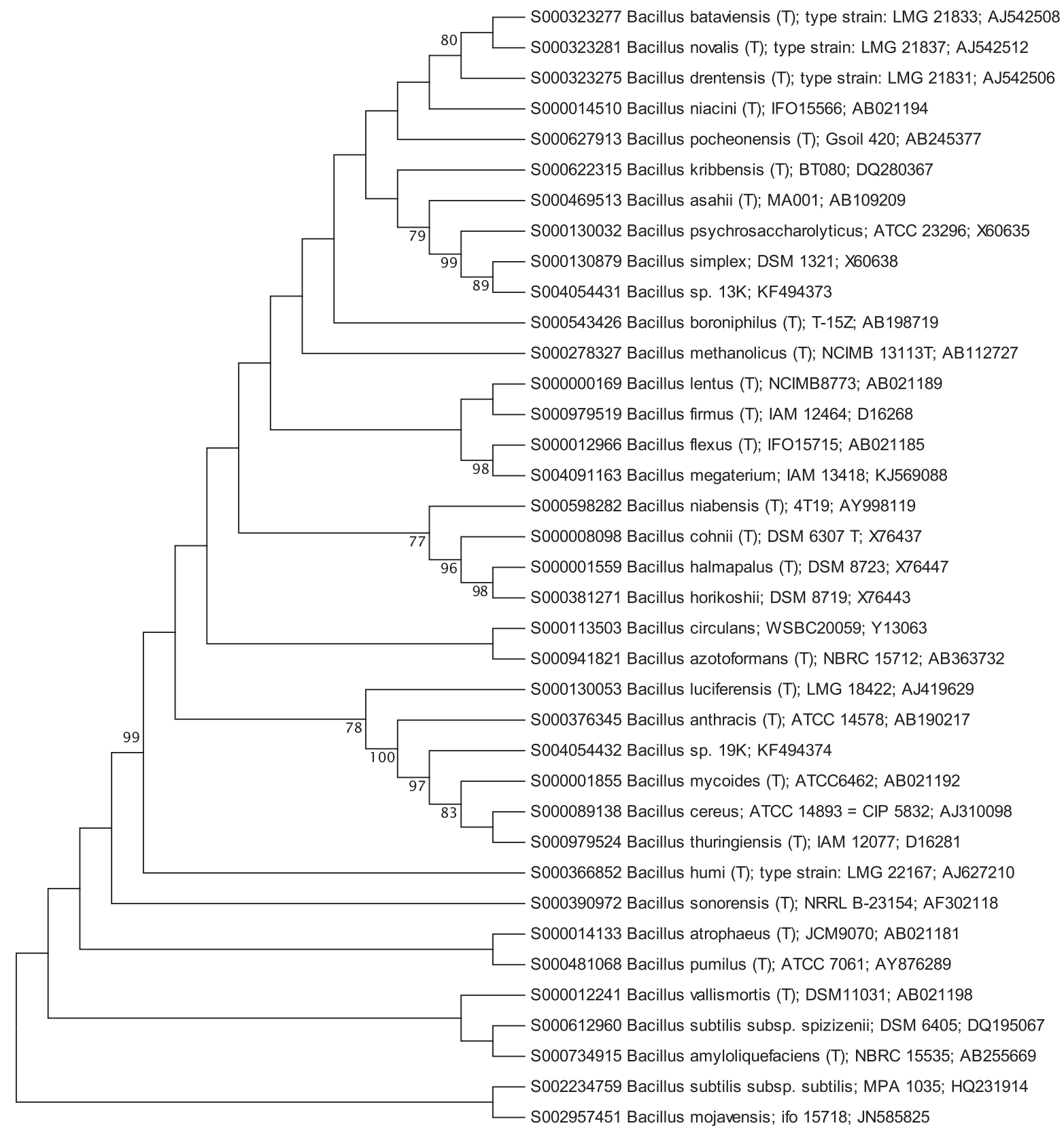

Fig. 2. A $16 \mathrm{~S}$ rRNA gene phylogeny placing isolates $13 \mathrm{k}$ and $19 \mathrm{k}$ in soil Bacillus spp. Bootstrap values above the cut-off (75\%) are shown. 

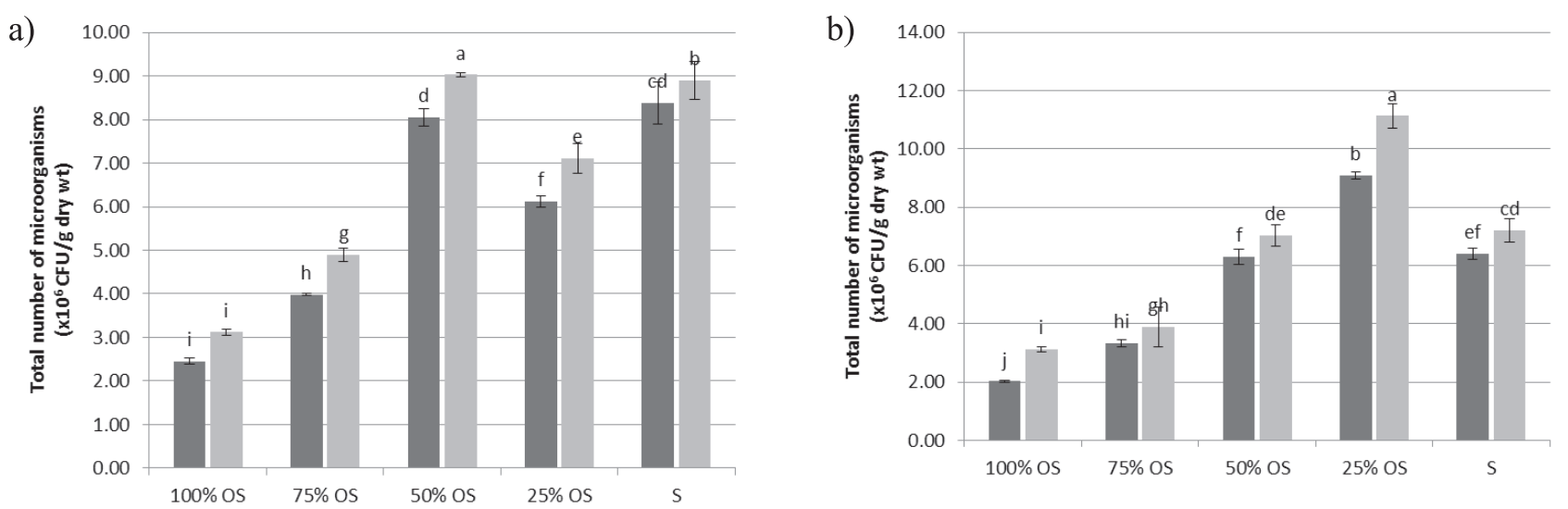

Fig. 3. Mean total number of microorganisms in oat (a) and lettuce (b), non-inoculated and inoculated overburden (OS) substrates. Means depicted with the same letter do not significantly differ according to Fisher's LSD test $(p=0.05)$.

Given that members of the Bacillus genus exhibit PGP activities $[24,32]$, we used $13 \mathrm{k} / 19 \mathrm{k}$ to co-inoculate the seeded substrates. The co-inoculum caused an increase in the total number of microorganisms in $100 \%$ OS from $2.45 \times 10^{6}$ to $3.12 \times 10^{6} \mathrm{CFU} / \mathrm{g}$ (oat) and from $2.02 \times 10^{6}$ to $3.12 \times 10^{6} \mathrm{CFU} / \mathrm{g}$ (lettuce) (Fig. 3). These stimulating effects of autochthonous Bacillus species on overall microbial activity in pure OS samples were also mirrored in DHA activity levels (Table 2). The same trend was observed upon the addition of soil, while 50:50 OS-to-S ratio mimicked the microbial abundance of inoculated fertile soil (Fig. 3). a) 120

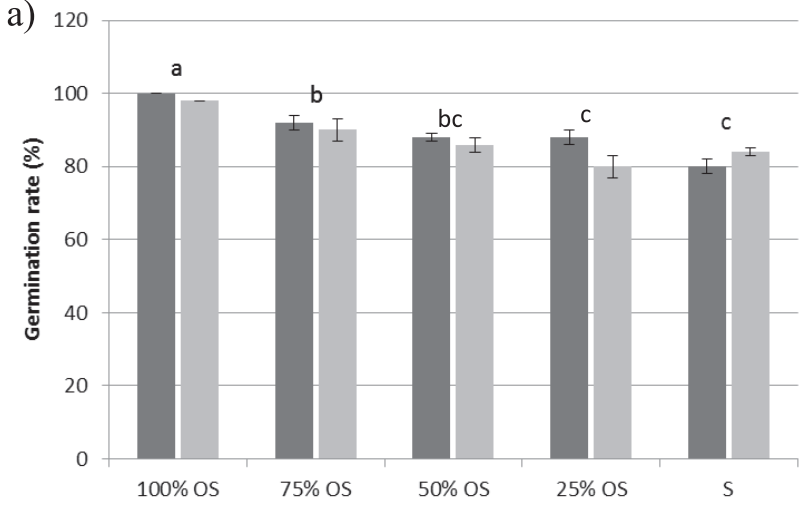

b)

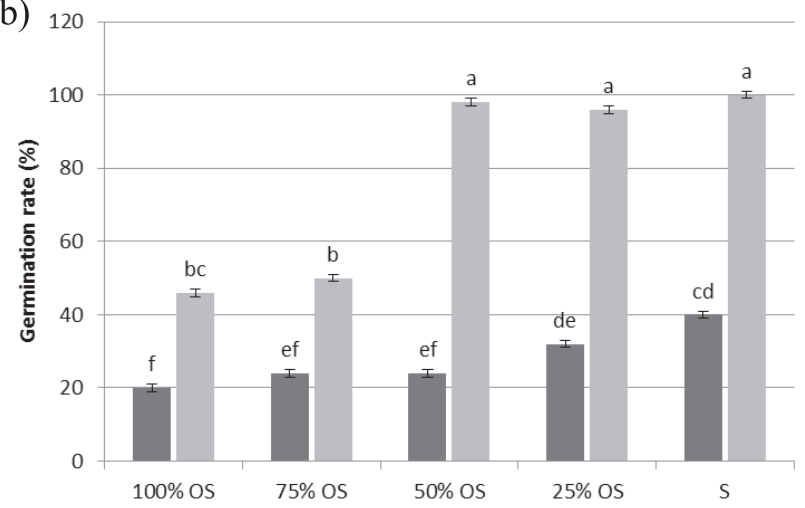

Fig. 4. Oat (a) and letuce (b) germination rates (\%) in non-inoculated and inoculated overburden soil (OS) substrates. Means depicted with the same letter do not significantly differ according to Fisher's LSD test $(p=0.05)$.

a)

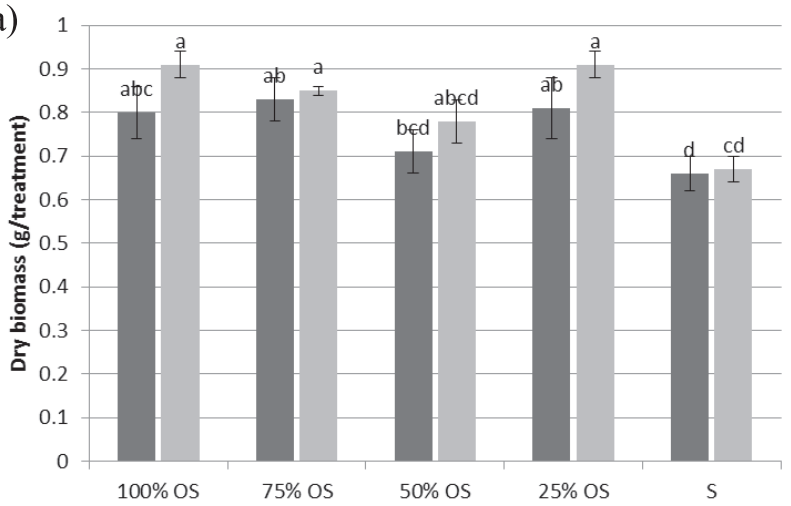

b)

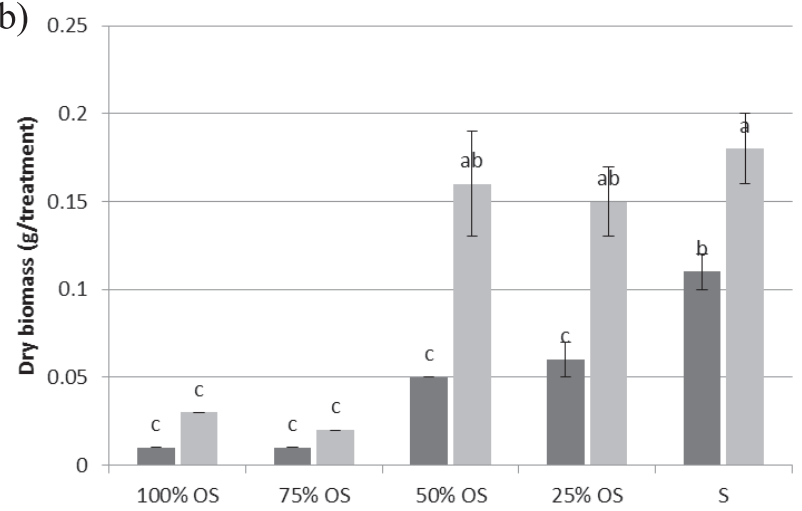

Fig. 5. Oat (a) and letuce (b) dry biomass in non-inoculated and inoculated overburden soil (OS) substrates. Means depicted with the same letter do not significantly differ according to Fisher's LSD test $(\mathrm{p}=0.05)$. 
Effect of $13 \mathrm{k}$ and $19 \mathrm{k}$ Co-Inoculation on Oat and Lettuce Growth Parameters

The addition of soil alone, as well as co-inoculation of substrates with $13 \mathrm{k} / 19 \mathrm{k}$, did not significantly alter oat's germination rate (Fig. 4a) and dry biomass (Fig. 5a). For instance, oat germination rate in $100 \%$ OS was $100 \%$ and $98 \%$ in non-inoculated and inoculated pots, respectively (Fig. 4a), while dry biomass was $0.8 \mathrm{~g} /$ substrate and $0.91 \mathrm{~g} /$ substrate (Fig. 5a). Our results illustrate that $A$. sativa's growth is not impaired in soil contaminated by metals and organic pollutants. This unresponsiveness to soil toxicity has also been seen by others, in studies of growth parameters and biochemical assays, performed on various soil types [33-35]. Given that oat's phytoextraction abilities allow removal of contaminants from soil, our results speak in favor of $A$. sativa's potential for bioremediation of lignite mine OS through re-vegetation. Yet this approach yields biomass accumulated with contaminants that could pose a significant health risk for humans, as well as domestic and wild animals.

With this constraint in mind, we also tested Lactuca sativa L. growth under varying conditions. Lettuce noninoculated $50 \%$ OS germination rate was $24 \%$, compared to $40 \%$ in $\mathrm{S}$, while non-inoculated $50 \%$ OS dry biomass was $0.05 \mathrm{~g} /$ substrate, compared to $0.11 \mathrm{~g} /$ substrate in $\mathrm{S}$ (Figs $4 \mathrm{~b}$ and $5 \mathrm{~b}$ ). Thus the addition of soil alone did not notably improve lettuce growth parameters and they never reached the levels seen in S (Figs $4 \mathrm{~b}$ and 5b). Coinoculation with $13 \mathrm{k} / 19 \mathrm{k}$, on the other hand, significantly increased lettuce germination in all substrate types, in comparison to respective non-inoculated substrates (Fig. $4 b)$. The level of germination in fertile soil and a significant stimulation of lettuce dry biomass were achieved in 50:50 OS-to-S ratio (Figs 4 and 5).

\section{Conclusions}

We have isolated and identified two lignite OS native bacteria, B. simplex and a $B$. cereus group member. To our knowledge, this represents the first microbial characterization of mine waste in $\mathrm{BiH}$. Previous research has demonstrated the ability of $B$. simplex to accumulate metals, such as $\mathrm{Cd}, \mathrm{Co}, \mathrm{Ni}$, and $\mathrm{Sr}$ [36], as well as to promote plant growth by altering plant root architecture, i.e., by stimulating the emergence of more lateral roots [24]. Studies have also shown PGP activities of B. cereus [37] and other group members, such as $B$. thuringiensis [38], as well as the potential role of $B$. thuringiensis in biodegradation of organophosphorus in contaminated soil [39]. Our results suggest that autochthonous B. simplex and $B$. cereus group bacteria are candidates for the bioremediation of lignite mine waste. We acknowledge that soil-assisted strategies are not always economically feasible and complicate infrastructure. Thus we are further exploring the potential roles of other previously reported PGP Bacillus spp., such as B. subtilis [40], B. amyloliquefaciens [41], B. pumilus [10], B. licheniformis
[42], and B. megaterium [43], plus other autochthonous bacterial species, alone or together with re-vegetation, in bioremediation of lignite mine waste.

\section{Acknowledgements}

Financial support for this work was provided by the EU Commission project AREA, contract No. 316004, as well as the Serbian Ministry of Education, Science and Technological Development Project Nos. TR31080, TR34019, and III43001.

\section{References}

1. DOKA G. Life Cycle Inventory of the disposal of lignite spoil, coal spoil and coal tailings, Doka Life Cycle 18; St. Gallen, Switzerland, 2009.

2. CHERNAIK M. Guidebook for evaluating mining project EIAs; Environmental Law Alliance Worldwide: Eugene, US, 2010.

3. BORBELY G., NAGY E. Removal of zinc and nickel ions by complexation-membrane filtration process from industrial wastewater. Desalination. 240 (1), 218, 2009.

4. OK Y.S., KIM S.C., KIM D.K., SKOUSEN J.G., LEE J.S., CHEONG Y.W., KIM S.J., YANG J.E. Ameliorants to immobilize $\mathrm{Cd}$ in rice paddy soils contaminated by abandoned metal mines in Korea. Environ. Geochem. Hlth. 33 (1), 23, 2011.

5. GERHARDT K.E., HUANG X.D., GLICK B.R., GREENBERG B.M. Phytoremediation and rhizoremediation of organic soil contaminants: potential and challenges. Plant Sci. 176 (1), 20, 2009.

6. FILCHEVA E., NOUSTOROVA, M., GENTCHEVAKOSTADINOVA S., HAIGH M.J. Organic accumulation and microbial action in surface coal-mine spoils, Pernik, Bulgaria. Ecol. Eng. 15 (1), 1, 2000.

7. MATHIZAYHAGAN N., NATARAJAN D. Bioremediation on effluents from Magnesite and Bauxite mines using Thiobacillus Spp and Pseudomonas Spp. J. Bioremed. Biodeg. 2, 115, 2011.

8. GOVARTHANAN M.J., CHO M., KIM J.S., KAMALAKANNAN S., OH B.T. Significance of autochthonous Bacillus sp. KK1 on biomineralization of lead in mine tailings. Chemosphere. 90 (8), 2267, 2013.

9. GRANDLIC C.J., MENDEZ M.O., CHOROVER J., MACHADO B., MAIER R.M. Plant growth-promoting bacteria for phytostabilization of mine tailings. Environ. Sci. Techno. 42 (6), 2079, 2008.

10. DE-BASHAN L.E., HERNANDEZ J.P., BASHAN Y., MAIER R.M. Bacillus pumilus ES4: Candidate plant growth-promoting bacterium to enhance establishment of plants in mine tailings. Environ. Exp. Bot. 69 (3), 343, 2010.

11. JUWARKAR A.A., SINGH S.K. Microbe-assisted phytoremediation approach for ecological restoration of zinc mine spoil dump. Int. J. Environ. Pollut. 43 (1), 236, 2010.

12. STABLEZ W.G. The mineral industries of the Southern Balkans. Minerals Yearbook 3, 2006.

13. JAKOVLJEVIĆ M., PANTOVIĆ M., BLAGOJEVIĆ S. Laboratory Manual of Soil and Water Chemistry (in Serbian); Faculty of Agriculture: Belgrade, Serbia, 1995.

14. CASIDA L., KLEIN D., SANTORO T. Soil Dehydrogenase Activity. Soil Sci. 98, 371, 1964. 
15. TAMURA K., STECHER G., PETERSON D., FILIPSKI A., KUMAR S. MEGA 6: Molecular Evolutionary Genetics Analysis Version 6.0. Mol. Biol. Evol. 30, 2725, 2013.

16. LINDSAY W.L., NORVELL W.A. Development of a DTPA soil test for zinc, iron, manganese and copper. Soil. Sci. Soc. Am. J. 42, 421, 1978

17. MAITI S.K., GHOSE M.K. Ecological restoration of acidic coal mine overburden dumps- an Indian case study. Land Contam. Reclam. 13 (4), 361, 2005.

18. EGAMBERDIYEVA D., JURAEVA D., HAITOV B., GAFUROVA L. Microbial and biochemical changes induced by rotation and tillage in a calcareous soil under melon, tomato, wheat and cotton production. In Proc. Southern Conserv. Tillage Conf. 224, 2005.

19. MARTYNIUK S., MARTYNIUK M. Occurrence of Azotobacter spp. in some Polish soils. Pol. J. Environ. Stud. 12 (3), 371, 2003.

20. LENART A. Occurrence, characteristics and genetic diversity of Azotobacter chroococcum in various soils of Southern Pol. J. Environ. Stud. 21 (2), 415, 2012.

21. WOLINSKA A., STEPNIEWSKA Z. Dehydrogenase activity in the soil environment. In Canuto R.A. (ed.): Dehydrogenases. Intech, Rijeka, 2012.

22. JARVAN M., EDESI L., ADAMSON A., VOSA T. Soil microbial communities and dehydrogenase activity depending on farming systems. Plant Soil Environ. 60 (10), 459, 2014.

23. FRANCIS I., HOLSTERS M., VEREECKE D. The Gram-positive side of plant-microbe interactions. Environ. Microbiol. 12 (1), 1, 2010.

24. SCHWARTZ A.R., ORTIZ I., MAYMON M., HERBOLD C.W., FUJISHIGE N.A., VIJANDERAN J.A., VILLELLA W., HANAMOTO K., DIENER A., SANDERS E.R., DEMASON D.A., HIRSCH A.M. Bacillus simplex-a little known PGPB with anti-fungal activity-alters pea legume root architecture and nodule morphology when coinoculated with Rhizobium leguminosarum bv. viciae. Agronomy. 3, 595, 2013.

25. ZHANG H.B., YANG M.X., SHI W., ZHENG Y., SHA T., ZHAO Z.W. Bacterial diversity in mine tailings compared by cultivation and cultivation-independent methods and their resistance to lead and cadmium. Microb. Ecol. 54 (4), 705, 2007.

26. HEYRMAN J., LOGAN N.A., RODRIGUEZ-DIAZ M., SCHELDEMAN P., LEBBE L., SWINGS J., HEYNDRICKX M., DE VOS P. Study of mural painting isolates, leading to the transfer of Bacillus maroccanus and Bacillus carotarum to Bacillus simplex, emended description of Bacillus simplex, re-examination of the strains previously attributed to Bacillus macroides and description of Bacillus muralis sp. nov. Int. J. Syst. Evol. 55 (1), 119, 2005.

27. RASKO D.A., ALTHERR M.R., HAN C.S., RAVEL J. Genomics of the Bacillus cereus group of organisms. FEMS Microbiol. Rev. 29, 303, 2005.

28. VILAS-BOAS G.T., PERUCA A.P.S., ARANTES O. M. N. Biology and taxonomy of Bacillus cereus, Bacillus anthracis, and Bacillus thuringiensis. Can. J. Microbiol. 53 (6), 673, 2007.

29. DOLGEN D., ALPASLAN M.N., DELEN N. Use of an agro-industry treatment plant sludge on iceberg lettuce growth. Ecol. Eng. 23 (2), 117, 2004.
30. PARVEZ S., VENKATARAMAN C., MUKHERJI S. A review on advantages of implementing luminescence inhibition test Vibrio fischeri for acute toxicity prediction of chemicals. Environ. Int. 32 (2), 265, 2006.

31. YAO J., ALLEN C. Chemotaxis is required for virulence and competitive fitness of the bacterial wilt pathogen Ralstonia solanacearum. J. Bacteriol. 188, 3697, 2006.

32. KLOEPPER J.W., RYU C.M., ZHANG S. Induced systemic resistance and promotion of plant growth by Bacillus spp. Phytopathology. 94, 1259, 2004.

33. LOUREIRO S., SANTOS C., PINTO G., COSTA A., MONTEIRO M., NOGUEIRA A.J., SOARES A.M. Toxicity assessment of two soils from Jales Mine (Portugal) using plants: Growth and biochemical parameters. Arch. Environ. Con. Tox. 50 (2), 182, 2006.

34. HERNANDEZ-ALLICA J., BECERRIL J.M., GARBISU C. Assessment of the phytoextraction potential of high biomass crop plants. Environ. Pollut. 152 (1), 32, 2008.

35. GINES G., JESUS M., PASTOR PINEIRO J., HERNANDEZ A.J. Effect of heavy metals from mine soils on Avena sativa L. and education strategies. Fresen. Environ. Bull. 19, 2083, 2010.

36. VALENTINE, N.B., BOLTON J.H., KINGSLEY M.T., DRAKE G.R., BALKWILL D.L., PLYMALE A.E. Biosorption of cadmium, cobalt, nickel, and strontium by a Bacillus simplex strain isolated from the vadose zone. J. Ind. Microbiol. 16 (3), 189, 1996.

37. HANDELSMAN J., RAFFEL S., MESTER E.H., WUNDERLICH L., GRAU C.R. Biological control of dampingoff of alfalfa seedlings with Bacillus cereus UW85. Appl. Environ. Microb. 56 (3), 713, 1990.

38. BAI Y., ZHOU X., SMITH D.L. Enhanced Soybean Plant Growth Resulting from Coinoculation of Strains with Bradyrhizobium japonicum. Crop Sci. 43 (5), 1774, 2003.

39. ZEINAT KAMAL M., NASHWA A. H., MOHAMED A. I., SHERIF E. N. Biodegradation and detoxification of malathion by Bacillus thuringiensis MOS-5. Austral. J. Bas. Appl. Sci. 2(3), 724-732, 2008.

40. ZHANG H., MURZELLO C., SUN Y., KIM M. S., XIE X., JETER R. M., ZAK J. C. DOWD S. E., PARE P. W. Choline and osmotic-stress tolerance induced in Arabidopsis by the soil microbe Bacillus subtilis (GB03). Mol. Plant Microbe In. 23, 1097-1104, 2010.

41. IDRIS E. E., IGLESIAS D. J., TALON M., BORRISS R. Tryptophan-dependent production of indole-3-acetic acid (IAA) affects level of plant growth promotion by Bacillus amyloliquefaciens FZB42. Mol. Plant Microbe In. 20, 619626, 2007.

42. PROBANYA A., MATEOS J.L., GARCIA J.L., RAMOS B., DEFELIPE M.R., MANERO F.G. Effects of inoculation with PGPR Bacillus and Pisolithus tinctorius on Pinus pinea $\mathrm{L}$. growth, bacterial rhizosphere colonization, and mycorrhizal infection. Microb. Ecol. 41 (2), 140, 2001.

43. LOPEZ-BUCIO J., CAMPOS-CUEVAS J.C., HERNANDEZ-CALDERON E., VELASQUEZ-BECERRA C., FARIAS-RODRIGUEZ R., MACIAS-RODRIGUEZ L.I., VALENCIA-CANTERO E. Bacillus megaterium rhizobacteria promote growth and alter root-system architecture through an auxin-and ethylene-independent signaling mechanism in Arabidopsis thaliana. Mol. Plant Microbe In. 20, 207, 2007. 
